\title{
PERTANGGUNGJAWABAN PIDANA TERHADAP ANAK PELAKU PENCABULAN YANG MELANGGAR PASAL 76 UNDANG-UNDANG NOMOR 35 TAHUN 2014 TENTANG PERLINDUNGAN ANAK DI WILAYAH PENGADILAN NEGERI BEKASI
}

\author{
Elfirda Ade Putri \\ Fakultas Hukum, Universitas Bhayangkara Jakarta Raya \\ elfirda.ade@dsn.ubharajaya.ac.id
}

\begin{tabular}{|c|c|c|}
\hline Naskah diterima: & Revisi: & Naskah disetujui: \\
$19 / 08 / 2019$ & $20 / 09 / 2019$ & $10 / 10 / 2019$ \\
\hline
\end{tabular}

\begin{abstract}
Abstrak
Penerapan sanksi pidana terhadap pelaku tindak pidana pencabulan tidak hanya terhadap orang dewasa saja, tetapi juga diterapkan terhadap anak pelaku tindak pidana pencabulan. Pengertian tentang anak dapat ditemukan dalam Undang-Undang Republik Indonesia Nomor 35 Tahun 2014 tentang Perlindungan Anak (disingkat UUPA). Pasal 1 angka 1 UUPA memberikan pengertian atas anak sebagai seseorang yang belum berusia 18 (delapan belas) tahun, termasuk yang masih berada dalam kandungan. Pencabulan kepada anak oleh anak dapat dijerat dengan Pasal 76 D dan E UU No.35 tahun 2014 tentang Perlindungan Anak. Anak yang belum berusia 12 tahun dan melakukan tindak pencabulan tidak dapat dikenai pertanggungjawaban pidana. Anak yang telah berusia 12 tahun tetapi belum berusia 14 tahun tidak dapat dijatuhi sanksi pidana apabila mereka melakukan pencabulan, hanya dapat dikenai tindakan. Pertanggungjawaban apapun yang diterapkan kepada anak yang melakukan pencabulan harus memperhatikan harkat dan martabat anak serta memperhatikan kepentingan terbaik anak. Jangan sampai stigma atau label akibat pertanggungjawaban pidana yang dibebankan kepada anak merusak masa depannya.
\end{abstract}

Kata kunci: Pertanggungjawaban pidana, Anak, Pelaku Pencabulan.

\begin{abstract}
The application of penalties against molestation is not only against adults, but also applies to children who commit the crime of molestation. An understanding of children can be found in the Law of the Republic of Indonesia Number 35 of 2014 concerning Child Protection (abbreviated as BAL). Article 1 number 1 of the BAL provides an understanding of a child as someone who has not participated in 18 (eighteen) years, including those who are still in the womb. Child abuse can be ensnared under Article 76 D and E of Law No. 35 of 2014 concerning Child Protection. Children who have not recovered 12 years and committed acts of sexual abuse cannot be liable for criminal liability. Children who have won 12 years but have not yet reached 14 years cannot be sentenced for the approval of those who commit molestation, only subject to action. Any accountability that is applied to children who commit sexual abuse must pay attention to the dignity of the child and pay attention to the child's best interests. Do not get stigmatized or labeled for the liability of penalties imposed on children who fail to receive.
\end{abstract}

Keyword: Criminal liability, Children, Abuse perpetrator. 


\section{Pendahuluan}

Anak merupakan karunia yang diberikan oleh Tuhan Yang Maha Esa untuk dibina dan dijaga. Seorang anak merupakan amanah yang dalam dirinya melekat harkat dan martabat yang berhak mendapatkan perlindungan hukum serta mendapatkan hak tanpa ia minta. Dalam Pasal 1 angka 2 Undang-Undang Nomor 23 Tahun 2002 tentang Perlindungan Anak, mengatakan bahwa:

"Perlindungan anak adalah segala kegiatan untuk menjamin dan melindungi anak dan hak-haknya agar dapat hidup, tumbuh, berkembang, dan berpartisipasi, secara optimal sesuai dengan harkat dan martabat kemanusiaan, serta mendapat perlindungan dari kekerasan dan diskriminasi"

Untuk mengatasi permasalahan yang dihadapi anak telah disahkan Undang-Undang (UU) Perlindungan Anak yaitu UU Nomor 23 Tahun 2002 Junto Undang-Undang Nomor 35 Tahun 2014 yang bertujuan untuk menjamin terpenuhinya hak-hak anak agar anak dapat hidup, tumbuh berkembang dan berpartisipasi secara optimal sesuai harkat dan martabat kemanusiaan serta mendapatkan perlindungan dari kekerasan dan diskriminasi demi terwujudnya anak Indonesia yang berkualitas berakhlak mulia dan sejahtera.

Negara Republik Indonesia telah meratifikasi konvensi hak anak melalui Keppres No. 36 tahun 1990. Peratifikasian ini sebagai upaya negara untuk memberikan perlindungan terhadap anak di Indonesia. Dalam hukum nasional perlindungan khusus anak yang berhadapan dengan hukum juga diatur dalam Undang-Undang Nomor 35 Tahun 2014 Tentang Perubahan Atas Undang-Undang Nomor 23 tahun 2002 Tentang Perlindungan Anak. Namun dalam pelaksanaannya masih banyak persoalan-persoalan yang timbul khususnya dalam hal anak yang berkonflik dengan hukum.

Dalam membicarakan tentang perlindungan anak, objek dan subjek adalah pelayanan dan kegiatan perlindungan anak sama-sama mempunyai hak dan kewajiban. Seseorang berhak untuk ikut serta secara tekun dan gigih dalam setiap kegiatan perlindungan anak, bahwa setiap anak itu wajar dan berhak mendapat perlindungan mental, fisik, d al dari orang tua, anggota masyarakat dan negara. ${ }^{1}$ Perlindungan terhadap anak pada suatu masyarakat bangsa, merupakan tolak ukur peradaban bangsa tersebut, karenanya wajib diusahakan sesuai dengan kemampuan nusa dan bangsa. Kegiatan perlindungan anak merupakan suatu tindakan hukum yang berakibat hukum. ${ }^{2}$ Oleh karena itu, perlu adanya jaminan hukum bagi kegiatan perlindungan anak. Kepastian hukum perlu diusahakan demi

\footnotetext{
${ }^{1}$ Shanti Delliyana, Wanita dan Anak di Mata Hukum, Yogyakarta: Liberty, 1988, hlm.15.

${ }^{2}$ Abdul G. Nusantara, Hukum dan Hak-Hak Anak, disunting oleh Mulyana W, Jakarta: Rajawali, 1986, hlm.23.
} 
Pertanggungjawaban Pidana Terhadap Anak Pelaku Pencabulan Yang Melanggar Pasal 76 Undang-Undang Nomor 35 Tahun 2014 Tentang Perlindungan Anak ... - Elfirda Ade Putri

kegiatan kelangsungan perlindungan anak dan mencegah penyelewengan yang membawa akibat dampak negatif yang tidak diinginkan dalam pelaksanaan kegiatan perlindungan anak. $^{3}$

\section{Permasalahan}

Upaya apa saja yang dilakukan dalam perlindungan hukum terhadap anak pelaku pencabulan berdasarkan Undang-Undang Nomor 35 Tahun 2014 Tentang Perubahan Atas Undang-Undang Nomor 23 tahun 2002 Tentang Perlindungan Anak?

\section{Metode Penelitian}

Metode penelitian hukum akan digunakan oleh penulis pada karya tulis ini adalah metode penelitian hukum yuridis-normatif. Soerjono Soekanto mengemukakan bahwa metode penelitian hukum yuridis-normatif atau yuridis-dogmatif adalah penelitian hukum yang dilakukan dengan cara meneliti bahan pustaka atau data sekunder. ${ }^{4}$

Penelitian hukum merupakan suatu proses untuk menemukan aturan hukum prinsipprinsip hukum maupun doktrin-doktrin hukum guna menjawab permasalahan hukum yang dihadapi hal tersebut sesuai dengan karakter perspektif ilmu hukum. berbeda dengan penelitian yang dilakukan di dalam bidang keilmuan yang bersikap deskriptif yang menguji kebenaran ada tidaknya sesuatu fakta yang disebabkan oleh suatu faktor tertentu penelitian hukum dilakukan untuk menghasilkan argumentasi, teori atau konsep baru sebagai preskripsi dalam menyelesaikan masalah yang dihadapi.

Jika pada keilmuan yang bersifat deskriptif jawaban yang diharapkan adalah true (benar) atau false (salah), maka langkah jawaban yang diharapkan Dalam penelitian hukum adalah right, appropriate, inappropriate, wrong. dengan demikian dapat dikatakan bahwa hasil yang diperoleh di dalam penelitian hukum sudah mengandung nilai. ${ }^{5}$

Data sekunder adalah data yang sudah didokumentasikan sehingga merupakan data yang sudah siap pakai. Penulis menggunakan pendekatan yuridis normatif oleh karena sasaran penelitian ini adalah hukum atau kaedah (norm). Pengertian kaedah meliputi asas hukum, kaedah dalam arti sempit (value), peraturan hukum konkret. Penelitian yang

\footnotetext{
${ }^{3}$ Arif Gosita, Masalah Korban Kejahatan, Jakarta: Akademika Pressindo, 1993, hlm.222.

${ }^{4}$ Hotma Pardomuan Sibuea dan Heryberthus Sukartono, Metode Penelitian Hukum, Jakarta: Krakatauw Book, 2009, hlm. 79.

${ }^{5}$ Peter Mahmud Marzuki, Penelitian Hukum, Jakarta: Kencana Pradana Media Grub, 2007, hlm 35.
} 
berobjekan hukum normatif berupa asas-asas hukum, sistem hukum, taraf sinkronisasi vertikal dan horisontal. ${ }^{6}$

Penelitian yang digunakan adalah penelitian hukum normatif, yaitu penelitian yang berfokus pada norma hukum positif berupa peraturan perundang-undangan. Penelitian ini bersifat deskriptif analitis yang artinya bahwa hasil penelitian ini berusaha memberikan gambaran secara menyeluruh, mendalam, tentang suatu keadaan atau gejala yang diteliti.

\section{Pembahasan}

Perlindungan hukum adalah memberikan pengayoman kepada hak asasi manusia yang dirugikan orang lain dan perlindungan tersebut diberikan kepada masyarakat agar mereka dapat menikmati semua hak-hak yang diberikan oleh hukum atau dengan kata lain perlindungan hukum adalah berbagai upaya hukum yang harus diberikan oleh aparat penegak hukum untuk memberikan rasa aman, baik secara pikiran maupun fisik dari gangguan dan berbagai ancaman dari pihak manapun. ${ }^{7}$

Perlindungan Hukum Terhadap Anak, Perlindungan hukum adalah segala daya upaya yang dilakukan secara sadar oleh setiap orang maupun lembaga pemerintah, swasta yang bertujuan mengusahakan pengamanan, penguasaan dan pemenuhan kesejahteraan hidup sesuai dengan hakhak asasi yang ada sebagaimana diatur dalam Undang-Undang No. 39 Tahun 1999 tentang Hak Asasi Manusia. Setiap anak Indonesia adalah aset bangsa yang sangat berharga, generasi penerus dan sumber daya manusia Indonesia yang bakal menjadi penentu masa depan bangsa dan negara. Negara berkewajiban menciptakan rasa aman dan memberikan perlindungan hukum kepada setiap anak Indonesia agar mereka tumbuh serta berkembang secara wajar dan berperan serta dalam pembangunan.

Menurut Barda Nawawi Arief, perlindungan hukum terhadap anak adalah upaya perlindungan hukum terhadap berbagai kebebasan dan hak asasi anak (fundamental rights and freedoms of children) serta berbagai kepentingan yang berhubungan dengan kesejahteraan anak. ${ }^{8}$ Perlindungan anak adalah suatu kegiatan bersama yang bertujuan mengusahakan pengamanan, pengadaan, dan pemenuhan kesejahteraan rohaniah dan jasmaniah anak yang sesuai dengan kepentingannya dan hak asasinya. ${ }^{9}$ Mengenai

\footnotetext{
${ }^{6}$ Ibid. hlm. 10.

${ }^{7}$ Satjipto Rahardjo. Loc Cit. hlm. 74

${ }^{8}$ Barda Nawawi Arie, Penegakan Dan Pengembangan Hukum Pidana. Bandung: Citra Aditya Bakti, 1998, hlm.156.

${ }^{9}$ Arif Gosita, Masalah Korban Kejahatan. Jakarta: Bhuana Ilmu Poluler, 2004, hlm.18.
} 
perlindungan hukum bagi korban terdapat dua teori yaitu terori Retributive Justice dan teori Restorative Justice.

Kemudian keadilan, menurut Hans Kelsen, menurutnya keadilan tentu saja digunakan dalam hukum, dari segi kecocokan dengan hukum positif terutama kecocokan dengan undang- undang. Ia menggangap sesuatu yang adil hanya mengungkapkan nilai kecocokan relative dengan sebuah norma 'adil' hanya kata lain dari 'benar'. Sedangkan menurut Aristoteles, mengatakan bahwa keadilan adalah memberikan kepada setiap orang apa yang menjadi haknya. Selanjutnya, membagi keadilan menjadi dua bentuk yaitu; pertama, keadilan distributif, adalah keadilan yang ditentukan oleh pembuat undang-undang. Kedua, keadilan korektif, yaitu keadilan yang menjamin, mengawasi dan memelihara distribusi ini melawan seranganserangan ilegal. Fungsi korektif keadilan pada prinsipnya diatur oleh hakim dan menstabilkan kembali dengan cara mengembalikan milik korban yang bersangkutan atau dengan cara mengganti rugi atas miliknya yang hilang.

Keadilan mencerminkan bagaimana seseorang melihat tentang hakikat manusia dan bagaimana seseorang memperlakukan manusia. Begitu pula hakim mempunyai kebebasan sepenuhnya untuk menentukan jenis pidana dan tinggi rendahnya suatu pidana, hakim mempunyai kebebasan untuk bergerak pada batas minimum dan maksimum, pidana yang diatur dalam Undang-undang untuk tiaptiap tindak pidana. ${ }^{10}$ Dalam memberikan putusan terhadap suatu perkara pidana, seharusnya putusan hakim tersebut berisi alasan-alasan dan pertimbanganpertimbangan yang bisa memberikan rasa keadilan bagi terdakwa. Dimana dalam pertimbangan-pertimbangan itu dapat dibaca motivasi yang jelas dari tujuan putusan diambil, yaitu untuk menegakkan hukum (kepastian hukum) dan memberikan keadilan. ${ }^{11}$ Berlakunya KUHAP menjadi pegangan hakim dalam menciptakan keputusan-keputusan yang tepat dan harus dapat dipertanggung jawabkan

\section{a. Lex posterior derogat legi priori}

Dalam peraturan perundang-undangan dikenal adanya asas Lex posterior derogat legi priori yaitu undang-undang yang baru mengenyampingkan Undang-Undang yang lama maksudnya Jika ada Undang-Undang yang mengatur tentang suatu hal diganti atau diperbaharui dengan Undang-Undang yang baru Maka undang-undang yang lama tidak berlaku lagi. Adapun beberapa contoh dari asas ini yaitu Undang-Undang nomor 48 tahun 2009 tentang kekuasaan kehakiman Undang-Undang ini menggantikan Undang-Undang

\footnotetext{
${ }^{10}$ Soedarto, Kapita Selekta Hukum Pidana, Bandung, Alumni, 1986, hlm.78

${ }^{11}$ Nanda Agung Dewantara, Masalah Kebebasan Hakim Dalam Menangani Suatu Masalah Perkara Pidana, Jakarta, Aksara Persada Indonesia, 1987, hlm. 50.
} 
nomor 4 tahun 2004 tentang kekuasaan kehakiman dan Undang-Undang nomor 11 tahun 2012 tentang Sistem Peradilan Pidana Anak yang menggantikan Undang-Undang nomor 3 tahun 1997 tentang pengadilan anak tujuan dari asas ini adalah untuk menjamin adanya kepastian hukum bagi para pencari keadilan sehingga Salah satu tujuan hukum atau kepastian hukum dapat tercapai.

Asas ini menghendaki bahwa apabila terjadi pertentangan antara peraturan perundang-undangan yang secara hierarki lebih rendah dengan yang lebih tinggi, peraturan perundang-undangan yang hierarkinya lebih rendah tersebut harus disisihkan. ${ }^{12}$ Bagir Manan sebagaimana dikutip oleh A.A. Oka Mahendra menyatakan bahwa apabila substansi peraturan perundang-undangan yang lebih tinggi mengatur hal yang oleh undang-undang telah ditetapkan menjadi wewenang peraturan perundang-undangan yang lebih rendah, hal ini merupakan pengecualian terhadap asas ini. ${ }^{13}$

Anak yang melakukan tindak pidana pencabulan dengan diawali rayuan-rayuan terlebih dahulu terhadap korbannya, maka perbuatan tersebut melanggar Pasal 76E UUPA, yang menyatakan: "Setiap orang dilarang melakukan kekerasan atau ancaman kekerasan, memaksa, melakukan tipu muslihat, melakukan serangkaian kebohongan atau membujuk Anak untuk melakukan atau membiarkan dilakukan perbuatan cabul. Hukuman bagi yang melanggar Pasal 76E UUPA, diatur dalam Pasal 82 UUPA adalah: (1) Setiap orang yang melanggar ketentuan sebagaimana dimaksud dalam Pasal 76E dipidana dengan pidana penjara paling singkat 5 (lima) tahun dan paling lama 15 (lima belas) tahun dan denda paling banyak Rp 5.000.000.000,- (lima milyar rupiah). (2) Dalam hal tindak pidana sebagaimana dimaksud pada ayat (1) dilakukan oleh Orang Tua, Wali, Pengasuh Anak, pendidik / tenaga kependidikan, maka pidananya ditambah $1 / 3$ (sepertiga) dari ancaman pidana sebagaimana dimaksud pada ayat (1). Tindak pidana pencabulan yang dilakukan oleh pelaku di bawah umur dapat dimintai pertanggungjawaban pidana apabila umurnya telah mencapai 14 (empat belas) tahun. Jika saat melakukan tindak pidana si anak berumur diatas 12 (dua belas) tahun, tapi belum mencapai umur 14 (empat belas) tahun, maka ancaman pidana yang dapat diberikan kepada si anak adalah paling lama 1/2 (setengah) dari pidana penjara orang dewasa . Tapi, jika tindak pidana yang dilakukan oleh si anak diancam dengan pidana mati atau

\footnotetext{
${ }^{12}$ Peter Mahmud Marzuki. Penelitian Hukum. Edisi Revisi. Kencana Prenada, Jakarta: Media Group, 2014, hlm.139.

${ }^{13}$ http://ditjenpp.kemenkumham.go.id/htn-dan-puu/421-harmonisasi-peraturan-perundang undangan.html diakses pada tanggal 26 Desember 2018 pukul 19.30 WIB
} 
Pertanggungjawaban Pidana Terhadap Anak Pelaku Pencabulan Yang Melanggar Pasal 76 Undang-Undang Nomor 35 Tahun 2014 Tentang Perlindungan Anak ... - Elfirda Ade Putri

pidana penjara seumur hidup, maka pidana yang dijatuhkan adalah pidana penjara paling lama 10 (sepuluh) tahun. ${ }^{14}$

Secara umum Konvensi Hak-Hak Anak, dapat dikelompokkan dalam 4 (empat) kategori, antara lain:

a. Hak untuk kelangsungan hidup (The Right To Survival), yaitu hak-hak untuk melestarikan dan mempertahankan hidup (The Right of Live) dan hak untuk memperoleh standar kesehatan tertinggi dan perawatan yang sebaik-baiknya.

b. Hak terhadap perlindungan (Protections Rights) yaitu hak-hak dalam konvensi hak anak yang meliputi hak perlindungan dari diskriminasi, tindak kekerasan dan keterlantaran bagi anak yang tidak mempunyai keluarga bagi anak-anak pengungsi.

c. Hak untuk tumbuh kembang (Development Rights) yaitu hak-hak anak dalam Konvensi Hak-Hak Anak yang meliputi segala bentuk pendidikan (formal dan nonformal) dan hak untuk mencapai standar hidup yang layak bagi perkembangan fisik, mental, spiritual, moral dan sosial anak (the rights of standart of living).

d. Hak untuk berpartisipasi (Participation Rights), yaitu hak-hak anak yang meliputi hak untuk menyatakan pendapat dalam segala hal yang mempengaruhi anak (the rights of a child to express her/his views freely in all matters affecting the child). ${ }^{15}$

Penerapan sanksi pidana terhadap pelaku tindak pidana pencabulan tidak hanya terhadap orang dewasa saja, tetapi juga diterapkan terhadap anak pelaku tindak pidana pencabulan. Pengertian tentang anak dapat ditemukan dalam Undang-Undang Republik Indonesia Nomor 35 Tahun 2014 tentang Perlindungan Anak (disingkat UUPA). Pasal 1 angka 1 UUPA memberikan pengertian atas anak sebagai seseorang yang belum berusia 18 (delapan belas) tahun, termasuk yang masih berada dalam kandungan. ${ }^{16}$ Bentuk sanksi tindakan yang diberikan kepada Anak yang Berkonflik dengan Hukum, antara lain ${ }^{17}$ :

a) Pengembalian kepada orang tua/Wali;

b) Penyerahan kepada seseorang;

c) Perawatan di rumah sakit jiwa;

d) Perawatan di LPKS;

\footnotetext{
${ }^{14}$ Pasal 81 ayat (6) Undang-Undang Republik Indonesia Nomor 11 Tahun 2012 tentang Sistem Peradilan Pidana Anak.

${ }^{15}$ Mohammad Joni dan Zulchaina Z. Tanamas, Aspek Hukum Perlindungan Anak dalam Perspektif Konvensi Hak Anak, (Bandung: Citra Aditya Bakti, 1999), hal. 35.

${ }^{16}$ Pasal 1 angka 1 Undang-Undang Republik Indonesia Nomor 35 Tahun 2014 tentang Perlindungan Anak.

${ }^{17}$ Pasal 82 ayat (1) Undang-Undang Republik Indonesia Nomor 11 Tahun 2012 tentang Sistem Peradilan Pidana Anak.
} 
e) Kewajiban mengikuti pendidikan formal dan/atau pelatihan yang diadakan oleh pemerintah atau badan swasta;

f) Pencabutan surat izin mengemudi; dan/atau

g) Perbaikan akibat perbuatan pidana.

Pada kasus tindak pidana pencabulan yang dilakukan oleh anak yang melanggar Pasal 76E UUPA, maka diversi tidak dapat diupayakan, karena dalam kasus ini bagi pelanggar Pasal 76 UUPA dijerat dengan pidana penjara paling lama 15 (lima belas) tahun dan denda paling banyak Rp 5.000.000.000,- (lima milyar rupiah) (Pasal 82 ayat (1) UUPA). Oleh karena itu, dalam kasus tindak pidana pencabulan yang dilakukan oleh anak, hakim tidak dapat memberikan putusan berupa diversi, tetapi berupa sanksi tindakan sesuai dengan Pasal 82 ayat (1) UUSPPA.

\section{Simpulan}

Bagi anak yang melakukan tindak pencabulan kepada anak berdasarkan UndangUndang Sistem Peradilan Pidana Anak di Indonesia apabila pelaku berusia 14 tahun tetapi belum genap 18 tahun dapat dikenakan sanksi pidana sebagaimana diatur dalam Pasal 71 atau tindakan yang diatur dalam Pasal 82 UU SPPA. Diversi tidak dapat diterapkan pada kasus ini dengan usia anak sebagaimana tersebut di atas karena syarat diversi sebagaimana ditegaskan dalam Pasal 7 ayat 2 UU SPPA khususnya tentang batas maksimum ancaman pidana yang dapat memperoleh diversi tidak terpenuhi. Apabila pelaku pencabulan berusia 12 tahun tetapi belum berusia 14 tahun tidak dapat dijatuhi sanksi pidana apabila mereka melakukan pencabulan, hanya dapat dikenai tindakan. Hal ini ditegaskan dalam Pasal 69 ayat 2 UU SPPPA. Sedangkan bagi pelaku pencabulan yang belum berusia 12 tahun dan melakukan tindak pencabulan tidak dapat dikenai pertanggungjawaban pidana.

\section{Saran}

Apapun pertanggungjawaban yang diterapkan kepada anak yang melakukan pencabulan harus memperhatikan harkat dan martabat anak serta memperhatikan kepentingan terbaik anak. Jangan sampai stigma atau label akibat pertanggungjawaban pidana yang dibebankan kepada anak merusak masa depannya.

\section{Daftar Pustaka}

Barda Nawawi Arief, , Bunga Rampai Kebijakan Hukum Pidana, PT Citra Aditya 
Pertanggungjawaban Pidana Terhadap Anak Pelaku Pencabulan Yang Melanggar Pasal 76 Undang-Undang Nomor 35

Tahun 2014 Tentang Perlindungan Anak ... - Elfirda Ade Putri

Bakti,Bandung, 2002.

Dendy Sugono, Kamus Besar Bahasa Indonesia, Jakarta : Kementerian

Pendidikan. 2011.

Dwidja Priyanto, Sistem Pelaksanaan Pidana Penjara Di Indonesia, Bandung : PT.

Rafika Aditama, 2009.

Erlinda, M.Pd., Upaya Peningkatan Anak dari Bahaya Kekerasan, Pelecehan dan

Eksploitasi, Komisi Perlindungan Anak Indonesia, 2014.

Eddy O.S.Hiariej. 2014. Prinsip-Prinsip Hukum Pidana. Cahaya Atma Pustaka,

Yogyakarta.

Hotma Pardomuan Sibuea dan Heryberthus Sukartono, Metode Penelitian Hukum,

Jakarta: Krakatauw Book, 2009.

Ismantoro Dwi Yuwono. 2015. Penerapan Hukum Dalam Kasus Kekerasan

Seksual terhadap Anak, Pustaka Yustisia. Yogyakarta.

Leden Marpaung, Asas-Teori-Praktek Hukum Pidana, Jakarta : Sinar Grafika, 2009.

M.Nasir Jamil. 2013. Anak Bukan untuk Dihukum. Sinar Grafika. Jakarta.

Nurul Chomaria. 2014. Pelecehan Anak, Kenali dan Tangani. Tinta Medina. Solo.

R.Soesilo.1996. Kitab Undang-Undang Hukum Pidana (KUHP) Serta Komentar-

Komentarnya Lengkap Pasal Demi Pasal. Politeia. Bogor.

Sudarto, Kapita Selekta Hukum Pidana, Bandung: Alumni, 1981.

Satjipto Rahardjo. 2009. Biarkan Hukum Mengalir. Penerbit Buku Kompas.

Jakarta.

Undang-Undang Dasar Republik Indonesia Tahun 1945.

Undang-Undang Nomor 11 Tahun 2012 tentang Sistem Peradilan Pidana Anak.

Undang-Undang Nomor 35 Tahun 2014 tentang Perlindungan Anak 